\title{
Team Work, Respect for People, Outcome Orientation, Innovation, Stability and Attention to Details in Determining Employees' Organizational Commitment
}

\author{
Muhammad Alfani ${ }^{1}$, Sulastini ${ }^{2}$, Dwi Wahyu Artiningsih ${ }^{3}$ \\ Universitas Islam Kalimantan Muhammad Arsyad Al-Banjari, Banjarmasin, Indonesia
}

\begin{abstract}
Employees Organizational Commitment (OCB) has received much attention in the past decade as scholars have recognized its significant effect on the success of organizations. The current research aims at enriching our understanding of commitment in the private university setting by identifying the main factors that may promote this behaviour among private university lecturers. Specifically, the research objectives are to analyse the effect of Team Work, Respect for People, Outcome Orientation, Innovation, Stability and Attention to Details to Employees Organizational Commitment of private university lecturers. The research was conducted on sampling of 91 respondents in South Kalimantan Province Indonesia with regression analysis design. The results indicate that all variables under investigation significantly contribute to the development of organizational commitment bringing the implication to the management that these variables must be considered when formulating human resources management strategy.
\end{abstract}

Keywords: Team Work, Respect for People, Outcome Orientation, Innovation, Stability, Attention to Details, Organizational Commitment.

\section{INTRODUCTION}

Cross-cultural studies of organizational commitment have been examined in several countries such as Canada, Great Britain, Belgium, Australia, Russia, South Korea, Japan, Singapore (e.g; Lee, Allen, Meyer, \& Rhee, 2001; Vandenberghe, 2003, Sue et.al, 2009). With increasing globalization and awareness of cultural issues that bear on social, cognitive, and attitudinal issues in the workplace of Indonesian employees (e.g., Rajiani, 2011), extending research on organizational commitment to other borders is important. Organizations in Indonesia are structured and run differently from their overseas counterparts in terms of recruitment, promotion, work environment, and political expectations. As such, private university lecturers in Banjarmasin, Indonesia may have different views and motivations toward their job. In addition, the cultural orientations of Banjarese people are somewhat dissimilar to other Indonesian living in other parts of islands. Given these differences, it is possible that the factors that influence organizational commitment of employees would be different in Banjarmasin compared to other parts of Indonesia.

Realizing the significance of employees' organizational commitment in formulating the human resources management strategy, the overall objective of this study is to provide practitioners with an insight on how they can enhance the level of EOC within their organization mainly in the setting of private university lecturers which is rarely explored. Specifically, the study will explore the association between employees' organizational commitment (EOC) with the six dimensions of culture attributed to O'Reilly, Chatman and Caldwell's (1991) Organizational Culture Profile (OCP) measure: team work, respect for people, outcome orientation, innovation, stability and attention to details. This way, the problem in research is formulated as follows:

1. Does team work positively affect private university lecturers' organizational commitment?

2. Does respect for people positively affect private university lecturers' organizational commitment?

3. Does outcome orientation positively affect private university lecturers' organizational commitment?

4. Does innovation positively affect private university lecturers' organizational commitment?

5. Does stability positively affect private university lecturers' organizational commitment? 
6. Does attention to details positively affect private university lecturers' organizational commitment?

7. Do team work, respect for people, outcome orientation, innovation, stability and attention to details altogether positively affect private university lecturers' organizational commitment?

\section{LiteratURE REVIEW}

The literature will highlight variables connecting the commitment in the area of organisational culture together with the dimensions forming these variables.

\subsection{Employees' Organizational Commitment}

There are many definitions of commitment, such as: an attitude that reflects feelings such as attachment, identification or loyalty to the object of the commitment (Morrow, 1993). Porter, Steers, Mowday, and their associates (e.g., Mowday, Steers \& Porter, 1979; Porter et al.,1974 ) clarifies organizational commitment represents an employee's (a) strong belief in and acceptance of the organization's goal and values; (b) a willingness to exert considerable effort on behalf of the organization; and (c) a strong desire to maintain membership. Although this definition has been refined by more recent researchers (e.g., Meyer, Allen, \& Smith, 1993), its basic concepts of the employee's identification with and attachment to the organization's values and practices have been accepted by most researchers.

Meyer and Allen (2004) identified three dimensions of organizational commitment which allow researchers and practitioners to examine why employees form greater commitment towards their organizations. These dimensions are "affective commitment" (i.e., commitment as an affective attachment to the organization), "continuance commitment" (i.e., commitment as a perceived cost associated with leaving the organization), and "normative commitment" (i.e., commitment as an obligation to remain in the organization). Since continuance and normative commitment is beyond the control of management (Su, et al., 2009), this study assesses the level of affective commitment.

\subsection{Organisational Culture}

The notion of culture is expressed by Furnham (2004): the unique configuration of norms, values, beliefs, way of behaving that characterise the manner in which groups and individuals combine to get the thing done. This means, that culture is a unique configuration of norms, values, beliefs, and ways of acting that characterise the ways in which groups and individuals join forces to respond to the meaning echoed in transactional conversation.

O'Reilly et al.'s (1991) Organizational Culture Profile (OCP) instrument is used as the measure of organizational culture in the present study. This measure consists of 26 items and has been used extensively (McKinnon et al. 2003; Baird, Harrison and Reeve 2007, Su et al., 2009) with similar findings in regard to the dimensions of culture: team work; respect for people; outcome orientation; innovation; stability; and attention to detail.

Team work refers to the extent to which employees within a firm cooperate with each other and work in unison towards overall organizational goals. The importance of teams has been emphasized in the modern economy as they can increase employees' flexibility and productivity which are both essential components for organizational success (Bishop, Scott and Burroughs 2000). Gil, Alcover and Peiro (2005) suggested that teams empower greater responsibility to team members thereby increasing their involvement and commitment to work.

Respect for people refers to the extent to which business units focus on fairness, respect for the rights of the individual, and tolerance (Windsor and Ashkanasy 1996). Being respected by the organization can increase employees' commitment to their organization (Tyler 1999). Specifically, employees who are treated with genuine respect and fairness are more likely to behave with loyalty and hard work. McKinnon et al. (2003) found a positive association between respect for people and the level of EOC in a Taiwan organization. It is expected that a similar result will be found in Banjarmasin, Indonesia as the importance of value and respect is universal.

Outcome orientation refers to the extent to which business units emphasize action and results, have high expectations for performance, and are competitive (O'Reilly et al. 1991). Nystrom (1993) argued that employees feel more committed in organizations that focus on pragmatic values where results are more important than processes. Hofstede (1998) also suggested that employees in organizations with a process-oriented culture perceive themselves as risk-averse and only exert the minimum amount of 
effort on their work, while in outcome oriented organizations, employees perceive that everyday can bring new challenges and exert maximum effort into their work. McKinnon et al. (2003) treated the link between outcome orientation and the level of EOC as an empirical question with the results demonstrating a positive relationship. Similar findings are expected in the current study.

Innovation represents a business unit's receptivity and adaptability to change, and its willingness to experiment (O'Reilly et al. 1991). Innovative organizations are more likely to experiment with new practices and their employees are more likely to respond positively to new techniques (Baird et al. 2007).

Stability refers to security of employment (Windsor and Ashkanasy 1996). It represents the extent to which an organization provides stable employment for employees (Windsor and Ashkanasy 1996) and employees' perceptions that the employment will continue as long as they exert the appropriate effort in their job (Valletta 1999). Morris, Lydka and O'Creevy (1993) argue that job security will only exhibit a strong positive relationship with employees' commitment to organizations during recessionary economic conditions.

Attention to detail is defined as a strict compliance with detailed rules and procedures in terms of precision and accuracy (O'Reilly et al. 1991). The phrase 'initiation of structure' refers to the degree to which managers define the roles of their subordinates in job-related activities, specify procedures, and assign tasks (Kohli 1989). Hence, organizations with a high degree of initiation of structure are indicative of a culture which emphasizes 'attention to detail'. Agarwal, Decarlo and Vyas (1999) and Lok and Crawford (2001) suggest that there is no direct relationship between initiation of structure and the level of EOC.

Based on above description, the following hypothesis is formulated:

1. Team work positively affects private university lecturers' organizational commitment.

2. Respect for people positively affects private university lecturers' organizational commitment.

3. Outcome orientation positively affects private university lecturers' organizational commitment.

4. Innovation positively affects private university lecturers' organizational commitment.

5. Stability positively affect private university lecturers' organizational commitment?

6. Attention to details positively affect private university lecturers' organizational commitment.

7. Team work, respect for people, outcome orientation, innovation, stability and attention to details altogether positively affect private university lecturers' organizational commitment.

\section{Methodology}

This study applies survey method with the correlational approach to examine the relationship between variables tested in the study using three independent variables through data obtained from questionnaires. The independent variable is Team Work (X1), Respect for People (X2) Outcome Orientation (X3), Innovation (X4) Stability (X5) and Attention to Details (X6) while the dependent variable is Organizational Commitment (Y).

The population of this study is 118 private university lecturers in the city of Banjarmasin, Indonesia where the determination of the sample is conducted by using random sampling with the following formula:

$\mathrm{n}=\mathrm{N} /\left(1+\mathrm{N} \cdot \mathrm{d}^{2}\right)$

where:

$\mathrm{n}=$ number of samples

$\mathrm{N}=$ population

$\mathrm{d}=$ precision

The calculation of the sample size with the formula generates:

$\mathrm{n}=118 /\left(1+118(0.05)^{2}\right)=91.11 \sim 91$ 
This way the sample size for this research is 91 out of 118 total population. Hypothesis testing is conducted by using regression analysis to determine the influence of one or more independent variables on the dependent variable. The linearity assumption are prerequisites to proceed to further test. Hypothesis testing is performed at a significance level of 0.05 .

\section{RESULT AND DISCUSSION}

The lecturers of listed organisations were asked to participate in the survey by responding their opinions for seven different measures in Team Work, Respect for People, Outcome Orientation, Innovation, Stability and Attention to Details and Employees' Organizational Commitment. The linearity test is performed with $F$-test. Data is linear as the value of each variable is above the critical value for F-test.

\subsection{Team Work and Employees' Organizational Commitment}

In order to test whether data from team work and employees' organizational commitment are linear, Ftest has been conducted. Since the F value as shown in table 1 is higher than the critical value of $F$ table, we can proceed to test the alternate hypothesis if team work is positively related to employees' organizational commitment within private university in Banjarmasin Indonesia. The strength of association of the two observed variable is detected from coefficient correlation $\left(r_{x 1}\right)=0.649$.

Tabel 1. Linearity test and coefficient of correlation of teamwork $\left(X_{1}\right)$ to employees' organizational commitment (Y)

\begin{tabular}{|l|l|l|l|l|l|}
\hline Observation & $\mathbf{R}$ & $\mathbf{R}^{\mathbf{2}}$ & $\mathbf{F}_{\text {-test }}$ & $\mathbf{F}_{\text {-tabel }} \alpha$ & \multirow{2}{*}{ Conclusion } \\
\cline { 1 - 4 } & $\mathbf{R}_{\mathbf{x} 1}$ & $\mathbf{r}_{\mathbf{x} 1}^{2}$ & $\mathbf{F}_{\mathbf{x} 1}$ & 0.05 & \\
\cline { 1 - 3 } & 0.649 & 0.421 & 91.53 & 0.42 & Significant \\
\hline
\end{tabular}

$\mathrm{F}_{\text {test }}=91.53$ is above critical value where $\mathrm{F}_{\text {-tabel }}$ for $(\square=0.05)$ is 0.42 indicating that the data is linear and eligible for the next process. Coefficient of correlation $\left(r_{x 1}\right)=0.649$ indicates a strong positive relationship between team work and employees' organizational commitment. Coefficient of determination $\left(\mathrm{r}_{\mathrm{x}}^{2} 1\right)=0.421$ indicates that contribution of team work to employees' organizational commitment is $42.1 \%$. This implies that when formulating human resources management strategy on the commitment of lecturers is that all faculty members must strengthen the team work to improve the commitment of lecturers.

\subsection{Respect for People and Employees' Organizational Commitment}

To test whether data from respect for people and employees' organizational commitment linear, F-test has been conducted. The higher $F$ value as shown in table 2 compared to the critical value of $F$ table indicates the appropriateness of the model to test the alternate hypothesis if respect for people is positively related to employees' organizational commitment within the organisation of private university lecturers in Banjarmasin Indonesia. The strength of association of respect for people $\left(\mathrm{X}_{2}\right)$ to employees' organizational commitment $(\mathrm{Y})$ is observable from coefficient correlation $\left(\mathrm{r}_{\mathrm{x} 2}\right)=0.452$.

Tabel 2. Linearity test and coefficient of correlation of respect for people $\left(X_{2}\right)$ to employees' organizational commitment $(Y)$

\begin{tabular}{|l|l|l|l|l|l|}
\hline Observation & $\mathbf{R}$ & $\mathbf{R}^{2}$ & $\mathbf{F}_{\text {-test }}$ & $\mathbf{F}_{\text {-tabel }} \alpha$ & \multirow{2}{*}{ Conclusion } \\
\cline { 1 - 1 } & $\mathbf{R}_{\mathbf{x} 2}$ & $\mathrm{r}_{\mathbf{x} 2}^{2}$ & $\mathbf{F}_{\mathbf{x} 2}$ & 0.05 & \\
\cline { 1 - 3 } & 0.452 & 0.204 & 24.30 & 0.42 & Significant \\
\hline
\end{tabular}

The table shows that $\mathrm{F}_{\text {test }}=24.30$ is above critical value where $\mathrm{F}_{\text {-tabel }}$ for $(\square=0.05)$ is 0.42 indicating that the data is linear and eligible for the next process. Coefficient of correlation $\left(r_{\mathrm{x} 2}\right)=0.452$ indicates a moderate positive relationship between respect for people and employees' organizational commitment. Coefficient of determination $\left(\mathrm{r}^{2}{ }_{\mathrm{x}} 2\right)=0.204$ indicates that contribution of respect for people to employees' organizational commitment is $20.4 \%$ while the rest $79.6 \%$ is determined by other factors not included in the model.

\subsection{Outcome Orientation and Employees' Organizational Commitment}

Similar to previous model, to identify if data from outcome orientation and employees' organizational commitment are linear, F-test has been conducted. The higher $F$ value as shown in table 3 compared to the critical value of $\mathrm{F}$ table indicates the appropriateness of the model to test the alternate hypothesis if outcome orientation is positively related to employees' organizational commitment 
Team Work, Respect for People, Outcome Orientation, Innovation, Stability and Attention to Details in Determining Employees' Organizational Commitment

within private universities in Banjarmasin, Indonesia. The strength of association of outcome orientation $\left(\mathrm{X}_{3}\right)$ to employees' organizational commitment $(\mathrm{Y})$ is observable from coefficient correlation $\left(\mathrm{r}_{\mathrm{x} 3}\right)=0.571$.

Tabel 3. Linearity test and coefficient of correlation of outcome orientation $\left(X_{3}\right)$ to employees' organizational commitment $(Y)$

\begin{tabular}{|l|l|l|l|l|l|}
\hline Observation & $\mathbf{R}$ & $\mathbf{R}^{2}$ & $\mathbf{F}_{\text {-test }}$ & $\mathbf{F}_{\text {-tabel }} \alpha$ & Conclusion \\
\cline { 1 - 4 } & $\mathbf{R}_{\mathbf{x} 3}$ & $\mathrm{r}_{\mathbf{x} 3}^{2}$ & $\mathbf{F}_{\mathbf{x} 3}$ & 0.05 & \\
\hline 91 & 0.571 & 0.326 & 47.00 & 0.42 & Significant \\
\hline
\end{tabular}

The table shows that $F_{\text {test }}=47.00$ is above critical value where $F_{\text {-tabel }}$ for $(\square=0.05$ )is 0.42 indicating that the data is linear and eligible for the next process. Coefficient of correlation $\left(r_{x 3}\right)=0.571$ indicates a moderate positive relationship between outcome orientation and employees' organizational commitment. Coefficient of determination $\left(\mathrm{r}^{2}{ }_{\mathrm{x} 3}\right)=0.326$ indicates that contribution of outcome orientation to employees' organizational commitment is $32.6 \%$ while the rest $67.4 \%$ is determined by other factors not included in the model.

\subsection{Innovation and Employees' Organizational Commitment}

By the same procedure, to identify if data from outcome innovation and employees' organizational commitment are linear, F-test has been conducted. The higher $\mathrm{F}$ value as shown in table 4 compared to the critical value of $\mathrm{F}$ table indicates the appropriateness of the model to test the alternate hypothesis if innovation is positively related to employees' organizational commitment within private universities in Banjarmasin, Indonesia. The strength of association of innovation $\left(\mathrm{X}_{4}\right)$ to employees' organizational commitment $(\mathrm{Y})$ is observable from coefficient correlation $\left(\mathrm{r}_{\mathrm{x} 4}\right)=0.052$.

Tabel 4. Linearity test and coefficient of correlation of innovation $\left(X_{4}\right)$ to employees' organizational commitment $(Y)$

\begin{tabular}{|l|l|l|l|l|l|}
\hline Observation & $\mathbf{R}$ & $\mathbf{R}^{2}$ & $\mathbf{F}_{\text {-test }}$ & $\mathbf{F}_{\text {-tabel }} \alpha$ & \multirow{2}{*}{ Conclusion } \\
\cline { 1 - 1 } & $\mathbf{R}_{\mathbf{x} 4}$ & $\mathbf{r}_{\mathbf{x} 4}^{2}$ & $\mathbf{F}_{\mathbf{x} 4}$ & 0.05 & \\
\cline { 1 - 3 } & 0.052 & 0.002 & 43.00 & 0.42 & Significant \\
\hline
\end{tabular}

The table shows that $F_{\text {test }}=43.00$ is above critical value where $F_{\text {-tabel }}$ for $(\square=0.05$ )is 0.42 indicating that the data is linear and eligible for the next process. Coefficient of correlation $\left(r_{x 4}\right)=0.052$ indicates a weak positive relationship between outcome innovation and employees' organizational commitment. Coefficient of determination $\left(\mathrm{r}^{2}{ }_{\mathrm{x} 4}\right)=0.002$ indicates that contribution of innovation to employees' organizational commitment is $0.02 \%$ while the rest $99.08 \%$ is determined by other factors not included in the model.

Drucker (1998) argues that innovation requires focused and hard work everyday rather than just genius, and therefore employees in innovative organizations will exhibit higher levels of EOC. A strong positive relationship between the culture dimension 'innovation' and the level of EOC was found in McKinnon et al. (2003). However, organization in Indonesia including Banjarmasin is in paternalistic environment. The well-defined hierarchy, with its explicit roles for each member (Hofstede, 1980), inhibits creativity and innovation (Ang and Hong, 2000). Further, face - a measure of social value - is an important concept to the Banjarese Indonesia. The potential loss of face from failure may discourage innovativeness. Therefore, in a culture where innovativeness is not encouraged, it becomes a differentiating cue that discriminates more from innovative and less innovative organizational culture. As such in this research, innovation is very lowly correlated to EOC.

\subsection{Stability and Employees' Organizational Commitment}

Applying the same procedure in identifying if data from stability and employees' organizational commitment are linear, F-test has been conducted. The higher $F$ value as shown in table 5 compared to the critical value of $\mathrm{F}$ table indicates the appropriateness of the model to test the alternate hypothesis if stability is positively related to employees' organizational commitment within private universities in Banjarmasin, Indonesia. The strength of association of stability $\left(\mathrm{X}_{5}\right)$ to employees' organizational commitment $(\mathrm{Y})$ is observable from coefficient correlation $\left(\mathrm{r}_{\mathrm{x} 5}\right)=0.172$. 
Tabel 5. Linearity test and coefficient of correlation of innovation $\left(X_{4}\right)$ to employees' organizational commitment $(Y)$

\begin{tabular}{|l|l|l|l|l|l|}
\hline Observation & $\mathbf{R}$ & $\mathbf{R}^{2}$ & $\mathbf{F}_{\text {-test }}$ & $\mathbf{F}_{\text {-tabel }} \alpha$ & \multirow{2}{*}{ Conclusion } \\
\cline { 1 - 1 } & $\mathbf{R}_{\mathbf{x} 5}$ & $\mathrm{r}_{\mathrm{x} 5}^{2}$ & $\mathbf{F}_{\mathbf{x} 5}$ & 0.05 & \\
\cline { 1 - 4 } & 0.172 & 0.029 & 52.00 & 0.42 & Significant \\
\hline
\end{tabular}

The table shows that $F_{\text {test }}=52.00$ is above critical value where $F_{\text {-tabel }}$ for $(\square=0.05)$ is 0.42 indicating that the data is linear and eligible for the next process. Coefficient of correlation $\left(r_{x 5}\right)=0.172$ indicates a weak positive relationship between outcome innovation and employees' organizational commitment. Coefficient of determination $\left(\mathrm{r}_{\mathrm{x} 5}^{2}\right)=0.029$ indicates that contribution of innovation to employees' organizational commitment is $2.9 \%$ while the rest $98.1 \%$ is determined by other factors not included in the model.

\subsection{Attention to Details and Employees' Organizational Commitment}

Applying the same procedure, the result for test for attention to details and employees' organizational commitment is depicted in Table 6.

Tabel 6. Linearity test and coefficient of correlation of attention to details $\left(X_{6}\right)$ to employees' organizational commitment $(Y)$

\begin{tabular}{|l|l|l|l|l|l|}
\hline Observation & $\mathbf{R}$ & $\mathbf{R}^{\mathbf{2}}$ & $\mathbf{F}_{\text {-test }}$ & $\mathbf{F}_{\text {-tabel }} \alpha$ & \multirow{2}{*}{ Conclusion } \\
\cline { 1 - 4 } & $\mathbf{R}_{\mathbf{x} 6}$ & $\mathbf{r}_{\mathbf{x} 6} \mathbf{F}_{\mathbf{x} 6}$ & 0.05 & \\
\cline { 1 - 3 } & 0.264 & 0.069 & 62.00 & 0.42 & Significant \\
\hline
\end{tabular}

The table shows that $F_{\text {test }}=62.00$ is above critical value where $F_{\text {-tabel }}$ for $(\square=0.05)$ is 0.42 indicating that the data is linear and eligible for the next process. Coefficient of correlation $\left(r_{x 6}\right)=0.264$ indicates a weak positive relationship between attention to details and employees' organizational commitment. Coefficient of determination $\left(\mathrm{r}^{2}{ }_{\mathrm{x} 6}\right)=0.069$ indicates that contribution of attention to details to employees' organizational commitment is $6.9 \%$ while the rest $93.1 \%$ is determined by other factors not included in the model.

\subsection{Team Work, Respect for People, Outcome Orientation, Innovation, Stability and Attention to Details in Determining Employees' Organizational Commitment}

When tested together the model is specified as:

$\hat{Y}=b_{0}+b_{1} x_{1}+b_{2} x_{2}+b_{3} x_{3}+b_{4} x_{4}+b_{5} x_{5}+b_{6} x_{6}+e$

Where:

$\hat{\mathrm{Y}}=$ Employees' Organizational Commitment

$\mathrm{b}_{0}=$ constant

$b_{1}, b_{2}, b_{3}, b_{4}, b_{5}, b_{6}=$ regression coeficient

$\mathrm{e}=$ error

$\mathrm{X}_{1}=$ Team Work

$\mathrm{X}_{2}=$ Respect for People

$\mathrm{X}_{3}=$ Outcome Orientation

$\mathrm{X}_{4}=$ Innovation

$\mathrm{X}_{5}=$ Stability

$\mathrm{X}_{6}=$ Attention to Details

Tabel 7. Multiple Regression Analysis Summary

\begin{tabular}{|l|l|l|l|l|l|l|l|}
\hline Model & $\beta$ & $\mathbf{R}$ & $\mathbf{R}^{2}$ & $\mathbf{F}_{\text {-test }}$ & \multicolumn{2}{|l|}{$\mathbf{F}_{\text {-tabel }} \alpha$} & Conclusion \\
\hline & & & & \multicolumn{3}{|l|}{$\mathbf{0 , 0 5}$} & \\
\hline & & & & 55.223 & 3.95 & Significant \\
\hline Constant & 22.12 & & & & & & \\
\hline Team Work & 0.46 & & & & & & \\
\hline Respect for People & 0.36 & 0.812 & 0.659 & & & & \\
\hline Outcome Orientation & 0.26 & & & & & & \\
\hline Innovation & 0.11 & & & & & & \\
\hline Stability & 0.19 & & & & & & \\
\hline Attention to Details & 0.21 & & & & & & \\
\hline
\end{tabular}


Tables 7 show the results of multiple regression analysis. The table reports a significant $F$ statistic, indicating that the model has strong prediction strength $(\mathrm{F}=55.223, \mathrm{p}<0.01)$. As further shown in Table 7, all variables altogether are strongly correlated to teachers' performance as shown by coefficient of correlation $=0.812$ and also affect employees' organizational commitment significantly as more than $60 \%$ of the variation in determination of private university lecturers is explained by the model $(\mathrm{R}$ Square $=0.659)$.

The model derives the following equation: $\hat{\mathrm{Y}}=22.12+0.46 \mathrm{X}_{1}+0.36 \mathrm{X}_{2}+0.26 \mathrm{X}_{3}+0.11 \mathrm{X}_{4}+0.19 \mathrm{X}_{5}$ $+0.21 \mathrm{X}_{6}$

Judging the value of regression coefficient from the highest to the lowest, this model reveals the team work $\left(\mathrm{X}_{1}\right)$ as the most dominant variable in determining the private university lecturers' organizational commitment followed by respect for people $\left(\mathrm{X}_{2}\right)$ and outome orientation $\left(\mathrm{X}_{3}\right)$. This bring implications that if the organization wishing to formulate a better human resources management strategy within the respective organization, these three variables must be given top priorities.

\section{Conclusion}

The findings conform that there is a positive and significant relationship between the Team Work, Respect for People, Outcome Orientation, Innovation, Stability and Attention to Details in Determining Employees' Organizational Commitment among lecturers working in private universities located in Banjarmasin, South Kalimantan Province, Indonesia. By refering to initial design of the interaction among variables, the results showed that the contribution of team work variable on employees' organizational commitment is $46 \%$, respect for people is $36 \%$, and outcome orientation is $26 \%$ indicating the highest individual contribution to the commitment of private university lecturers is team work out of six variables tested. When combined together, contribution of the the six independent variables mentioned above achieve 65.9 indicating the contribution of other variables not included in the model to predictprivate lecturers' organizational commitment are $34.1 \%$ indicating this model is of high goodness of fit. However, other researchers or practicioners of human resources manangement wishing to conduct similar studies may include other variables as though organizational culture has been widely studied, the finding confirm the notion on the importance of salient and specific of organizational culture in Indonesian setting which may be different among people across the country whose rich in cultures and values making human resources management strategy should be adapted to specific characteristics of those people in specific region in Indonesia (Rajiani, 2011).

\section{REFERENCES}

Agarwal, S., Decarlo, T.E., and Vyas, S.B. (1999). Leadership behaviour and organizational commitment: A comparative study of American and Indian salespersons. Journal of International Business Studies 30(4): 727-743.

Ang, Swee Hoon and Hong, Don G. P. (2000). Entrepreneurial spirit among East Asian Chinese. Thunderbird International Business Review 42(3): 285-309.

Baird, K., Harrison, G., and Reeve, R. (2007). Success of activity management practices: The influence of organizational and cultural factors. Accounting and Finance 47 (4): 47-67.

Bishop, J.W., Scott, K.D. and Burroughs, S.M. (2000). Support, commitment and employee outcomes in a team environment. Journal of Management Development 26 (6): 1113-1132.

Drucker, P.F. (1998). The discipline of innovation. Harvard Business Review 76(6): 149-157.

Furnham, A., Education and culture shock. Psychologist, 17(1), 16 (2004).

Gil, F., Alcover, C., and Peiro, J. (2005). Work team effectiveness in organizational contexts. Journal of Managerial Psychology 20 (3/4): 193-218.

Hofstede, G. (1998). Attitudes, values and organizational culture: Disentangling the concepts. Organization Studies 19(3): 477-492.

Kohli, A.K. (1989). Effects of supervisory behaviour: The role of individual differences among salespeople. Journal of Marketing Research 53 (October): 275-290.

Lee, K., Allen, N.J., Meyer, J.P. and Rhee, K. (2001) The three-component model of organizational commitment: An application to South Korea. Applied Psychology 50(4): 596-614. 
Lok, P. and Crawford, J. (2001). Antecedents of organizational commitment and the mediating role of job satisfaction. Journal of Managerial Psychology 16 (8): 594-613.

McKinnon, J.L., Harrison, G.L., Chow, C.W., and Wu, A. (2003). Organizational culture: Association with commitment, job satisfaction, propensity to remain, and information sharing in Taiwan. International Journal of Business Studies 11(1): 25-44.

Meyer, J.P. and Allen, N.J. (1991) A three-component conceptualization of organizational commitment. Human Resource Management Review 1: 61-89.

Meyer, J. P., \& Allen, N. J. (2004). TCM employee commitment survey academic users guide 2004. London, Ontario, Canada: The University of Western Ontario, Department of Psychology.

Morris, T., Lydka, H. and O'Creevy, M.F. (1993). Can commitment be managed? A longitudinal analysis of employee commitment and human resource policies. Human Resource Management Journal 3(4): 21-42.

Morrow, P.C. (1983) Concept redundancy in organizational research: the case of work commitment. Academy of Management Review 8: 486-500.

Mowday, R.T.,Steers, R.M., and Porter, L.W. (1979) The measurement of organizational commitment. Journal of Vocational Behavior 14: 224-247.

Nystrom, P. C. (1993) Organizational cultures, strategies, and commitments in health care organizations. Health Care Management Review 18(1):43-49.

O'Reilly, C. A., Chatman, J. A. and Caldwell, D. F. (1991) People and organizational culture: A profile comparison approach to assessing person-organization fit. Academy of Management Journal 34: 487-516.

Porter, L.W. Mowday, R.T. and Boulian, V. (1974) Organizational commitment, job satisfaction, and turnover among psychiatric technicians. Journal of Applied Psychology 5: 603- 609.

Rajiani, I. (2011). A Cultural Ecology of New Public Management in Indonesia. Journal of Administrative Science, 8(1), 17-31.

Su S, Baird K, Blair B (2009). Employee organizational commitment: the influence of cultural and organizational factors in the Australian manufacturing industry. International Journal of Human Resources Management 20(12): 2494- 2516.

Tyler, T.R. (1999). Why people cooperate with organizations: An identity-based perspective. Research in Organizational Behaviour 21: 201-246.

Valletta, R. (1999). Declining job security. Journal of Labour Economics 17 (4): S170-S197.

Vandenberghe, C. (2003). Application of the three-component model to China: issue and perspectives. Journal of Vocational Behavior 62(3): 516-523.

Windsor, C., \& Ashkanasy, N. (1996). Moral reasoning development and belief in a just world as precursors of auditor independence: The role of organizational culture perceptions. Behavioral Research in Accounting, 8, 80-97. 